\title{
ОЦІНКА СТАВЛЕННЯ МОЛОДІ ДО ПАРТНЕРСЬКИХ ПОЛОГІВ ЗА РЕЗУЛЬТАТАМИ АНКЕТУВАННЯ
}

\author{
Л. М. Маланчук, О. В. Лісіна, С. Л. Маланчук, В. М. Мартинюк, \\ А. С. Маланчук
}

Тернопільський національний медичний університет імені І. Я. Горбачевського МОЗ Украӥни

У статті проведено аналіз анкетних даних користувачів соціальної мережі «Instagram» щодо ставлення до партнерських пологів.

\section{ASSESSMENT OF THE ATTITUDE OF YOUNG PEOPLE TO PARTNER CHILDBIRTH BASED ON THE RESULTS OF THE SURVEY}

\section{M. Malanchuk, O. V. Lisina, S. L. Malanchuk, V. M. Martynyuk, A. S. Malanchuk}

\section{Horbachevsky Ternopil National Medical University}

In the article we analyze the personal data of users of the social network Instagram on the attitude to partner childbirth.

Вступ. Здоров'я матері та дитини є інтегральним показником соціально-економічного благополуччя в країні, потужним чинником формування працездатного та етнічно-культурного потенціалу держави. Гарантом розробки та реалізації програм, спрямованих на збереження репродуктивного здоров'я нації, формування організаційних і правових аспектів даного напрямку роботи, є держава з цілим інститутом відповідних органів [1].

За даними досліджень, на сьогодні спостерігають знижений моральний та культурний рівні допомоги роділлям, знецінення ролі сім'і та відповідального батьківства, ігнорування емоційними потребами вагітних, домінування гендерної дискримінації, насилля у сфері сімейних стосунків. Значні еміграційні процеси, які пов'язані з фінансовими труднощами, стали причиною руйнування шлюбних відносин, появою неповних сімей, втратою контролю сексуальної поведінки дітей та значним поширенням шкідливих звичок серед останніх. Усе це суттєво впливає на стан здоров'я людей, зокрема на репродуктивний потенціал [3].

Сформульована ВООЗ концепція безпечного материнства передбачає соціально-економічні, пра- вові та медичні аспекти народження дітей з урахуванням фізичних, психологічних та соціальних факторів благополуччя вагітної, роділлі та породіллі. Традиційний підхід до процесу ведення вагітності, пологів та післяпологового періоду позбавляє сім'ю психосоціального та культурного контенту родинноорієнтованих технологій і, як наслідок, розвиненої форми батьківства - усвідомленого батьківства, яке означає взяття на себе повної відповідальності за зачаття, народження дитини та їі виховання [2].

Партнерські пологи - це без сумніву складне випробування для родини, яке можна і треба пройти разом і залишитися щасливими. Згідно зі статистикою, 82 \% чоловіків, які були активними учасниками родинно-орієнтованих технологій, в подальшому пишалися своїм батьківством, відчували вдячність дружині за можливість разом із нею відчути всі емоційні переживання періоду народження нового життя [2].

31980 р. у багатьох країнах світу почалася активна пропаганда партнерських пологів за підтримки державних програм. Присутність чоловіка на пологах стала звичною практикою, а створення перина-

(с Л. М. Маланчук, О. В. Лісіна, С. Л. Маланчук, В. М. Мартинюк, А. С. Маланчук, 2021 
тальних центрів дозволило втілити у життя потребу жінок у впровадженні родинно-орієнтованих технологій [5].

Сучасні перинатальні технології асоціюються з новим поняттям «доула» - людиною/командою (помічником при родах), яка володіє знаннями інформаційної та психологічної підтримки, різними техніками знеболювання (акупресурою, технікою дихання), для максимально комфортного перебігу емоційно і фізично напруженого періоду материнства [1].

Сімейні пологи - це закономірний етап переходу до усвідомленого батьківства, шанобливого ставлення до жінки, відповідального виховання дітей, формування позитивного мікроклімату в родині, відновлення культури інституту сім'ї.

На сьогодні Інтернет став невід'ємною частиною нашого життя. Проте поруч із можливостями, які він дає для розвитку здібностей та розширення кола інтересів, він ще й містить реальні загрози як для дорослих, так особливо і для дітей. Вдале поєднання цього інструменту з іншими складовими впливу на репродуктивне здоров'я дозволить успішно вирішувати нагальну проблему щасливого материнства [6].

Основна частина. За даними офіційної статистики, в Україні у 2004 р. частка партнерських пологів склала менше 1 \% від усіх родорозрішень. У подальшому цей показник зріс до 70-80 \%, проте в 2020-2021 рр. за умов пандемії практика сімейних пологів суттєво обмежилася.

Особливу увагу приділяють питанням психологічної підтримки жінки під час пологів, ролі та завданням медичних працівників, які надають їй медичну допомогу. Ставлення до пологів змінювалося у розрізі століть разом із розвитком суспільства та його потреб. Технологічний прогрес медичної сфери та запити населення сприяли зміні місця приймання пологів із домашніх умов на лікарняні. Така практика мала на меті зменшити ризики для матері та дитини в процесі розродження та після пологів. Проте своєрідне технократичне бачення пологів із застосуванням багатьох інтервенцій з не завжди доведеною ефективністю призвело до втрати психологічної підтримки роділлі, обмеження ролі батька у найвідповідальнішу мить народження спадкоємця [4].

Впровадження практики родинно-орієнтованих технологій в Україні розпочало жваву дискусію щодо переваг та недоліків цієї програми. Першочерговим було визначити: які сподівання жінка очікує від підтримки на усіх етапах до щасливого материнства?
Оприлюднені результати численних досліджень у світі дали підстави для наступних висновків переваг сімейних пологів: постійний супровід жінки під час вагітності, пологів, післяпологового періоду забезпечив їй підтримку в емоційному, фізичному, інформаційному та посередницькому вимірах. Одначе ці ж дослідження вказали на ще одну важливу складову материнського благополуччя - відповідального батьківства: чоловік та жінка мають разом бажати пройти цей непростий шлях і бути готовими до труднощів. Відповідальна психопрофілактика під час вагітності $є$ дієвим інструментом адаптації у гестаційний період та при пологах, складовою практичних та теоретичних знань щодо процесу виношування та народження, базовою школою для батька з питань репродуктології та його ролі на всіх етапах цього процесу [3].

Ініціативна група студентів Подільського медичного фахового коледжу вирішила дослідити ставлення сучасної молоді до партнерських пологів, провівши опитування у соціальній мережі «Instagram».

В опитуванні взяло участь 449 людей. Усі респонденти дослідження давали відповіді на конкретні запитання (чоловіки - на 8 запитань, а жінки - на 7). Перші два запитання стосувалися віку та гендерного складу учасників анкетування.

Окрім того, оцінено відповіді на такі запитання:

- Ваше ставлення до партнерських пологів?

- Чи був у Вас досвід партнерських пологів?

- Чи хотіли б Ви взяти участь у партнерських пологах?

- На Вашу думку, чи може участь у партнерських пологах вплинути на подальше ставлення партнерів один до одного?

- Як Ви вважаєте, варто відвідувати школу відповідального батьківства?

- Взявши участь у партнерських пологах, чи наважились би Ви перерізати пуповину?

За віком усіх добровольців поділено на дві групи: молодші та старші 20 років. Жінки у групі 16-19 років склали 65 \%, а чоловіки - 35 \%. У віці 20 і більше років активність в опитуванні взяли порівну молоді люди обох статей.

На запитання «Ваше ставлення до партнерських пологів?» та «Чи був у Вас досвід партнерських пологів?», 70 \% учасників дослідження вказали на позитивне ставлення до присутності під час пологів близької людини, у 5 \% опитаних вже був досвід останніх. 
3 одного боку, пологи є фізіологічним процесом, а з іншого - дуже відповідальним моментом у житті родини. Тому, так важливо, щоб під час вагітності та пологів була створена атмосфера спокою, довіри, впевненості в успішному завершенні пологів. За таких обставин вагітна/роділля/породілля сприймається медичними працівниками не як об'єкт для проведення певних медичних маніпуляцій, а як індивідуум із правами головного режисера перинатальних подій.

На запитання «Чи хотіли 6 Ви взяти участь у партнерських пологах?» і «На Вашу думку, чи може участь у партнерських пологах вплинути на подальше ставлення партнерів один до одного?» отримано такі відповіді (табл. 1 і 2).

\section{Таблиця 1. Відповіді на запитання «Чи хотіли 6 Ви взяти участь у партнерських пологах?»}

\begin{tabular}{|l|l|}
\hline \multicolumn{1}{|c|}{ Відповідь } & \multicolumn{1}{c|}{ Результат } \\
\hline Так & 238 опитаних $-53 \%$ \\
\hline $\mathrm{Hi}$ & 211 опитаних $-47 \%$ \\
\hline
\end{tabular}

Таблиця 2. Відповіді на запитання «На Вашу думку, чи може участь у партнерських пологах вплинути на подальше ставлення партнерів один до одного?»

\begin{tabular}{|l|l|}
\hline \multicolumn{1}{|c|}{ Відповідь } & \multicolumn{1}{c|}{ Результат } \\
\hline Так & 309 опитаних $-69 \%$ \\
\hline $\mathrm{Hi}$ & 140 опитаних $-31 \%$ \\
\hline
\end{tabular}

69 \% опитаних вважають, що партнерські пологи - складне випробування для подружньої пари, що вплине на подальші стосунки один до одного.

Під час вагітності та особливо пологів роділля зазнає значних психоемоційних навантажень, що можуть призвести до порушення адаптаційних систем захисту нейроендокринної системи. Наукові дослідження підтверджують появу неспокійної поведінки плода на фоні стресу в матері. Формування пологової домінанти, впевненості у нормальному перебігу вагітності та пологів, подолання страху перед пологами та відчуття болю під час родового акту $є$ передумовою народження здорового малюка не лише у фізичному сенсі, але й психічному. Відмова батька у психоемоційній підтримці жінки протягом вагітності, пологів та в післяродовий період $\epsilon$ тригером розвитку стресу не тільки для матері, але й для плода, що значно пригнічує його фізіологічні пристосувальні рефлекси до напруженого акту пологів. У таких випадках зростає число недоношених вагітностей, оперативних розроджень, знижена оцінка новонароджених за шкалою Апгар, ускладнений перебіг транзиторних станів.

Більшість учасників анкетування (72 \%) вбачає у відповідальному батьківстві основу сімейного благополуччя та свідомо обирає навчання у школі, де отримує ці знання та навички.

Щоб сімейні пологи не стали розчаруванням для партнерів, стикнувшись з фізіологічною правдою, до них треба підійти свідомо та виважено, пройшовши відповідний курс навчання. Саме школа відповідального батьківства допоможе подружнім парам підготуватися до цього процесу.

Отримані результати на останнє запитання в анкеті, яке було адресовано партнерам, виявили цілу низку проблем, пов'язаних із реальною допомогою та підтримкою роділлі не на словах, а на ділі.

Загалом значна більшість сучасної молоді «за» спільні пологи. Молодь усвідомлює, що необхідна кваліфікована підготовка до партнерських пологів.

Тому наступні рекомендації партнеру щодо підтримки жінки під час вагітності та пологів будуть корисними:

- постійно підтримувати розмову з дружиною і виявляти зацікавленість у процесі перебігу вагітності, пологів та майбутнього догляду за дитиною;

- активно допомагати дружині під час вагітності та після пологів, у домашньому господарстві, бути ініціативним у відвідуванні школи відповідального батьківства;

- збагачувати свої знання та навички щодо допомоги під час вагітності, пологів та в післяпологовий період, адже у сім'і Вам відведена роль сильної половини. Варто не забувати про особливий емоційний стан майбутньої матері та бути терплячим і уважним до її проблем та хвилювань;

- особливу увагу необхідно приділити підготовці до самого процесу пологів і очікуваної миті народження первістка. Корисним буде разом із дружиною вивчити основні фізіологічні процеси, які відбуваються у трьох періодах пологів, бути готовим прийти на допомогу жінці у будь-яку мить, взяти на себе відповідальність за внутрішній спокій та емоційну підтримку роділлі.

За таких обставин Ви назавжди будете пов'язані не лише спільними дітьми, але й спогадами та відчуттям підтримки у найвідповідальнішу мить сімейного життя.

Висновки. Спільні пологи - це фінал спільної вагітності. Якщо пара свідомо підходить до питання 
зачаття, разом переживає всі стадії вагітності, то це цілком природно, щоб чоловік був присутній на пологах своєї дитини й допомагав своїй дружині.

\section{СПИСОК ЛІТЕРАТУРИ}

1. Бабич Т. Ю. Сімейні пологи: профілактика та зниження акушерських і перинатальних ускладнень : автореф. дис. на здобуття наук. ступеня д-ра мед. наук : 14.01.01 / Т. Ю. Бабич. - Донецьк, 2009. - 40 с.

2. Божук О. А. Гестаційна домінанта як маркер у визначенні становлення материнської сфери / О. А. Божук, Б. С. Божук // Укр. наук.-мед. молодіж. журн. 2012. - № 3. - С. 100-102.

3. Вдовиченко С. Ю. Акушерские и перинатальные аспекты партнерских родов / С. Ю. Вдовиченко // Актуальні проблеми акушерства і гінекології, клінічної імунології та медичної генетики : зб. наук. праць. - КиївЛуганськ, 2013. - Вип. 25. - С. 24-31.

4. Вдовиченко С. Ю. Відношення різних учасників партнерських пологів щодо тактики їх проведення /
Це золотий внесок до скарбниці спільної з жінкою духовності, значний внесок у сімейне будівництво.

С. Ю. Вдовиченко // Збірник науковихпраць співробітників НМАПО імені П. Л. Шупика : тези матеріалів науковопрактичного семінару з міжнародною участю «Здоров'я матері, плода та новонародженого в Україні», 14 травня 2015 року, м. Київ. - К., 2015. - Вип. 24. - С. 235.

5. Вдовиченко С. Ю. Дискуссионные вопросы партнерских родов с точки зрения их участников / С. Ю. Вдовиченко // Збірник наукових праць співробітників НМАПО імені П. Л. Шупика. - К., 2015. - Вип. 24. - С. 16-21.

6. Запорожан В. М. Підготовка до пологів з врахуванням психофізіологічних особливостей вагітних / В. М. Запорожан, А. В. Іовенко // Загальна патологія та патологічна фізіологія. - 2012. - Т. 7, № 1. - С. 151-155. 